Robin ORTON*

\title{
STRUGGLING WITH CHRISTOLOGY: APOLINARIUS OF LAODICEA AND ST GREGORY OF NYSSA
}

Sometime in the 380s, St Gregory of Nyssa wrote two works against the Christological teachings of Apolinarius of Laodicea. I have recently had published an English translation, with an introduction and commentary ${ }^{1}$, and this paper is something of a spin-off from that. It aims to look at the controversy between Gregory and Apolinarius in a specific theological context, that of the fourth century development of Christological doctrine which eventually led to the Chalcedonian definition of 451, and which established what the Western and Eastern Orthodox churches now accept as Christological orthodoxy.

Gregory's target in the more substantial of the works, the Antirrheticus adversus Apollinarium, is Apolinarius's book entitled "Demonstration ( $\dot{\alpha} \pi \delta \delta_{\varepsilon l} \xi 1 \varsigma$ ) of the divine enfleshment according to the likeness of a human being" I shall refer to this henceforth as the Apodeixis. It has not survived independently, and cannot be firmly dated, but it was probably the most mature representation of Apolinarius's Christological teaching. Gregory's Antirrheticus is our main source for the surviving fragments of the text of Apolinarius's Apodeixis, although there is no doubt that in many cases Gregory has distorted, misrepresented or misunderstood what Apolinarius wrote.

The earlier history and development of Apolinarius's Christology ${ }^{2}$ is difficult to reconstruct with any degree of certainty. Fierce arguments about Trinitarian doctrine dominated theological debate in the middle part of the fourth century, and Christological questions rarely took centre stage. Attitudes to Apolinarius's peculiar Christological doctrines, as they developed, perhaps in the 360s and 370 s, were complicated by the fact that on Trinitarian doctrine Apolinarius was very firmly in the pro-Nicene, anti-Arian camp. Although a version of Apollinarianism had been condemned by Pope Damasus in Rome in 376, the position in the East, at the time Gregory composed his Antirrheticus, was still in flux. In particular, Apollinarian doctrines were probably not explicitly discussed at the

* Dr Robin Orton - Visiting Research Fellow in Theology, Department of Theology \& Religious, King's College London; e-mail: robin.orton@kcl.ac.uk.

${ }^{1}$ St Gregory of Nyssa, Anti-Apollinarian Writings, translated with an introduction, commentary and notes by R. Orton, The Fathers of the Church 131, Washington DC 2015.

${ }^{2}$ For which see St Gregory of Nyssa, Anti-Apollinarian Writings, p. 7-28. 
Council of Constantinople in 381. Indeed, it was not until 388 that the imperial government unambiguously outlawed Apollinarianism throughout the empire, and that was almost certainly after the writing of the Antirrheticus, which was probably (although this remains controversial) in or around 383. So at the time of writing Gregory would have seen Apolinarius and his disciples as continuing to present a very real threat to the unity of the Church.

I believe that Apolinarius had three main concerns in the Apodeixis, all of which, like most Christological arguments, were primarily driven by soteriological considerations. Firstly, he wanted to make it clear that in order to save us, Jesus had to both fully divine and fully human ${ }^{3}$. He was opposed both to Arianism and to any form of docetism.

Secondly, he wanted to establish that there is nevertheless only one Christ. Again, the background is soteriological. Like Gregory and most of the earlier Eastern Fathers, Apolinarius did not usually see salvation as the Father's response to the atoning death of his Son. Instead he saw the divine Logos itself as the principal agent of our redemption: not only as teacher, law-giver and model for humanity but also as sanctifying and glorifying us by joining our human flesh to his divinity ${ }^{4}$ and raising us up, with him, from death to resurrection glory.

In order for this to happen, there must, Apolinarius believed, be ontic continuity between the Second Person of the Trinity and Christ in his two natures. In order to save us, the divine Logos must have "become flesh", by, to use the language of Philippians 2, "humbling" himself. He could not just have joined himself to the man Jesus; that would imply a clear separation between the human and divine natures and suggest that there are "two Christs". That is something that Christian theologians as far back as Irenaeus had been anxious to guard against ${ }^{5}$. Moreover, Apolinarius believed, it would have inevitably led to an "adoptionist" view of Christ as a "God-filled man" - that, he claims, is what was taught by Paul of Samosata in the third century and, more recently, by Marcellus of Ancyra and his pupil Photius of Sirmium ${ }^{6}$. It would have put Christ on the same level as the Old Testament prophets and could not therefore form the basis of an adequate soteriology.

Furthermore, the union between the two natures must be as close and indissoluble as can be conceived. The Chalcedonian formula was of course not yet available as a model for expressing this. In its absence, it appears that Apolinarius may have been led into some unguarded expressions about the comprehensiveness of the union and about its pre-ordained and almost metaphysically necessary nature. In what seems, so far as can be judged, an accurate citation

${ }^{3}$ Cf. ibidem, p. 44-45.

${ }^{4}$ Cf. J.N.D. Kelly, Early Christian Doctrines, London 19935 $183-88$.

${ }^{5}$ Cf. Irenaeus Lugdunensis, Adversus haereses III 16, 1 - 19, 3, PG 7, 919C - 938C.

${ }^{6} \mathrm{Cf}$. Gregorius Nyssenus, Antirrheticus adversus Apollinarium, ed. F. Müller, GNO 3/1, Leiden $1958,138$. 
from the Apodeixis, Gregory reports Apolinarius as having said that "the man Christ pre-existed, not with the Spirit, that is God, existing separately from him" . (I should explain that "Spirit" here refers to the second rather than to the third Person of the Trinity.) In other words, Apolinarius wanted to suggest that the possibility, indeed the inevitability, of the incarnation was in some sense eternally part of the Logos's eternal nature.

As an aside, I have often wondered how fair it would be to suggest that Apolinarius may here have been anticipating what I understand Karl Barth's view to have been, that there is no such thing as a pre-incarnate or un-incarnate

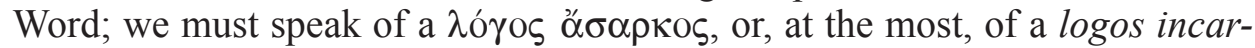
nandus ${ }^{8}$. I have not explored this further, but what one can say is that in doing so one would need to have regard to the totally different metaphysical frameworks within which Apolinarius and Gregory on the one hand, and Barth on the other, were theologizing.

At any rate Gregory is able to point to other statements of Apolinarius in a similar vein (although some of them he almost certainly, for whatever reason, misquotes.) He interprets them in what seems to have been a rather plodding and literalistic way. If Apolinarius believed that Christ had been enfleshed from all eternity, his flesh must have originated in heaven rather than in Mary's womb. That interpretation makes Apolinarius's Christology look ridiculous; it is however almost certainly a misunderstanding of what Apolinarius really wanted to say. Whatever Apolinarius's view might have been about the $\lambda$ ó $\gamma$ "ó $\sigma \propto к \kappa \varsigma$, , he explicitly denies that "the flesh of the Lord is from above and not from the Virgin Mary" - in fact in an earlier work he had anathematized those who hold this view?

Apolinarius's third concern was to demonstrate that Jesus could not have had a human mind. This was partly because of the difficulty of there being two potentially contradictory sources of knowledge and will in a single human being. That is of course a widely recognised difficulty in classical Christology, as is demonstrated by developments after Chalcedon, up to the seventh century monothelete controversy and perhaps beyond. The other was again soteriological. As mentioned above, Apolinarius saw Christ's saving role as one of sanctification, of restoring his and therefore our human nature to its original state of pure virtue. This, he believed, would be impossible if he had had a human mind, which is inherently, and, in his view, irredeemably, mutable and unstable ${ }^{10}$.

So his central notion, in the Apodeixis, is that the eternal Logos took the place of Jesus's human mind. In the context of the development of Christology

\footnotetext{
${ }^{7}$ Ibidem, GNO 3/1, 147.

${ }^{8}$ My original source for this was http://postbarthian.com/2014/08/26/logos-asarkos/[22.10.2016]. I subsequently found a useful summary of Barth's view (which has been further developed by Robert Jenson) in C. Gunton, The Barth Lectures, ed. P.H. Brazier, Edinburgh 2007, 167-170.

${ }^{9}$ St Gregory of Nyssa, Anti-Apollinarian Writings, p. 55-58.

${ }^{10} \mathrm{Cf}$. ibidem, p. 51-52 and 54-55.
} 
in the fourth century, this may well not in itself have been a particularly revolutionary view. The great pillar of orthodoxy, Athanasius himself, may well not have believed that Jesus had a human soul ${ }^{11}$, although the language of the Tomus ad Antiochenos, drawn up after the synod he convened at Alexandra in 361 is, perhaps intentionally, ambiguous - possibly in order to keep on board the representatives of Apolinarius who were present ${ }^{12}$ For him, as for Apolinarius, the soteriological significance of the incarnation was that humanity should be refashioned after the model of the divine Logos, the archetype of humanity in whose image Adam and Eve were created ${ }^{13}$. He was not particularly interested in the precise nature of Christ's humanity, and its relationship with his divinity. But, according to Charles Raven, he was nevertheless "an Apollinarian at heart"14.

Apolinarius goes on to make what is perhaps the most ingenious of his intellectual moves. He argues that, even without a human mind, Christ was truly a complete man and, as such, a single person. The defining characteristic of human beings is, he claimed, that they should comprise three separate elements, a body, a mind or "spirit" and an animal soul. Jesus Christ met this specification. The fact that the second element, the mind, the centre of Christ's identity and consciousness as it is of ours, was identified with the Second Person of the Trinity was neither here nor there.

Gregory argues convincingly however that Apolinarius's "enfleshed mind" Christology would mean that Jesus Christ was not fully human and could not therefore save humankind. He follows the spirit although not the letter of his friend's Gregory of Nazianzus's celebrated anti-Apollinarian dictum, often rendered as quod non est assumptum non est sanatum ${ }^{15}$. The human mind is affected by sin just as much as the human body, and is equally in need of salvation. It is true that only a creature with a rational mind can sin, but "the mind is not sin!" says Gregory ${ }^{16}$. He rejects Apolinarius's contention that our minds are inherently incapable of becoming what they were originally intended to be, the image and likeness of $\operatorname{God}^{17}$.

On the other hand, he accuses Apolinarius of over-emphasizing the ontic continuity between the eternal Logos and Jesus of Nazareth. Apolinarius goes

${ }^{11}$ Cf. Ch.E. Raven, Apollinarianism: An Essay on the Christology of the Early Church, Cambridge 1923, 94; F.M. Young - A. Teal, From Nicaea to Chalcedon: A Guide to the Literature and Its Background, London 2010², 249.

${ }^{12}$ Cf. St Gregory of Nyssa, Anti-Apollinarian Writings, p. 14, n. 36.

${ }^{13}$ Cf. Young - Teal, From Nicaea to Chalcedon, p. 55-56; Kelly, Early Christian Doctrines, p. 379.

${ }^{14}$ Raven, Apollinarianism, p. 114.

${ }^{15}$ Gregorius Nazianzenus, Epistula 101, PG 37, 181C.

${ }^{16}$ Gregorius Nyssenus, Antirrheticus adversus Apollinarium, GNO 3/1, 141.

${ }^{17}$ For this paragraph see St Gregory of Nyssa, Anti-Apollinarian Writings, p. 75. For the human mind as uniquely constituting the image and likeness of God, see Gregorius Nyssenus, Dialogus de anima et resurrectione, PG 46, 60C and idem, De oratione dominica, ed. J. Callahan, GNO VII/2, Leiden 1992, 32 or ed. J. Migne, PG 44, 1194C. 
so far, he says, as to claim that, in the incarnation, God himself is somehow transformed into a complex, and therefore inherently passible being, who can die on the cross. Gregory argues that it is an absurd and blasphemous idea that God should die ${ }^{18}$; even today, with the advantage of the Chalcedonian definition of the hypostatic union, many intelligent Christians (I'm not sure how many theologians!) would agree, as a quick Google search for "Did God die on the cross?" will demonstrate. In any case, Gregory believed that it was the divine Logos, "mixed" with Christ's humanity, rather than the Father, who effected the resurrection, That would have become impossible if the Logos had died with the man Jesus ${ }^{19}$.

Gregory also argued that Apolinarius's Christological model implies that the infinite God and the finite human mind are on the same ontological level, so the former could be substituted for the latter in the anthropological constitution of the incarnate $\mathrm{Christ}^{20}$. Using a contemporary analogy, it would treat God as something that could be as it were physically transplanted into the human body, or like someone claiming that God had been substituted for his left arm. This seems to me to be a fair argument so far as it goes. Nevertheless it may raise the question as to whether the same objection could not be levelled against the Chalcedonian formula. That too arguably similarly links together the infinite creator with the finite creature in a metaphysically puzzling, or at any rate mysterious, way.

But can it be said that in the face of Apolinarius's challenge Gregory is able to give an adequate alternative account of the unity of Christ's person? His main model for the relationship between the Christ's human and divine natures is that they were "mixed" in Mary's womb ${ }^{21}$. (Apolinarius also in fact on one occasion talks in what seem to be quite general terms of the two natures being "mixed" and Gregory commends him for doing $\mathrm{so}^{22}$.) In ancient philosophy there were a number of different understandings of how mixture worked and the extent to which the separate substances maintained their identity in the mixture ${ }^{23}$. The concept of mixture is nevertheless in any case Christologically problematic. It is in fact open to exactly the same objection as that which Gregory raises against Apolinarius's model - it implies that God and humanity are on the same ontological lever and can thus be "mixed" together like for example vinegar and water ${ }^{24}$.

Gregory clearly feels however that he has not yet adequately refuted Apolinarius's charge that he is teaching "two Christs". In response to this, the final

\footnotetext{
${ }^{18}$ Cf. St Gregory of Nyssa, Anti-Apollinarian Writings, p. 69.

${ }^{19} \mathrm{Cf}$ Gregorius Nyssenus, Antirrheticus adversus Apollinarium, GNO 3/1, 154.

${ }^{20}$ Cf. St Gregory of Nyssa, Anti-Apollinarian Writings, p. 70-71.

${ }^{21}$ Cf. ibidem, p. 77.

${ }^{22}$ Cf. Gregorius Nyssenus, Antirrheticus adversus Apollinarium, GNO 3/1, 217.

${ }^{23}$ Cf. St Gregory of Nyssa, Anti-Apollinarian Writings, p. 208, n. 403 and references given there.

${ }^{24}$ Cf. ibidem, p.78, n. 395.
} 
move he makes is in effect to develop and extend the concept, or metaphor, of mixture. He proposed that the complete unity between the two "mixed" natures was postponed until after Christ's glorification ${ }^{25}$. His divinity then overwhelmed his humanity and removed all his human characteristics. In a famous analogy, he compares this with the way the water of the sea overwhelms a drop of vinegar dropped into it - in other words on the basis of the Stoic understanding of mixture that Gregory seems to be adopting here, he is saying that although Christ's human nature was not, at the metaphysical level, obliterated at the time of his glorification, the properties associated with it were totally transformed ${ }^{26}$. On this basis he has, anachronistically but not unreasonably, been accused of taking a Nestorian view of Christ before his glorification and a miaphysite one after it.

But a defence can nevertheless be made of Gregory's Christological model, to the effect that it is oriented to soteriology rather than to metaphysics. Compared with the quasi-scientific anthropological schema offered by Apolinarius, it is fluid and dynamic - as Christ's human nature is overwhelmed by the divinity at his glorification, so will ours be, as we share his humanity and are members of his ecclesial body ${ }^{27}$. In the words of the celebrated "exchange formula", which in its basic form goes back to Irenaeus ${ }^{28}$, God became man so that man could become God.

In conclusion, the controversy between Gregory and Apolinarius demonstrates that, in the context of the history of dogma, both Gregory and Apolinarius can be seen as making significant contributions to the development of the Church's Christological teaching. Both Apolinarius's stress on the indivisible unity of Christ and Gregory's on the notion that "what is not assumed is not healed" were essential elements in what emerged seventy years later in the Chalcedonian definition.

\footnotetext{
${ }^{25}$ Recently rejected on what are not, in my view, very convincing grounds by Theodoros Alexopoulos, Die Christologie Gregors von Nyssa in Contra Eunomium III 3-4: Die Beweisführung Gregors zur Einheit der Person Christi und das Problem des Verhältnisses der zwei Naturen zueinander in Ihm. Ist der Verdacht des Monophysitismus bei Gregor berechtigt?, in: Gregory of Nyssa Contra Eunomium III, An English Translation with Commentary and Supporting Studies, Proceedings of the12th International Colloquium on Gregory of Nyssa (Leuven, 14-17 September 2010), ed. J. Leemans - M. Cassin, Supplements to Vigiliae Christianae 124, Leiden 2014, 486-487.

${ }^{26}$ Cf. St Gregory of Nyssa, Anti-Apollinarian Writings, p. 208, n. 43.

${ }^{27}$ Cf. ibidem, p. 70-71. I follow Hélène Grelier, L'argumentation de Grégoire de Nysse contre Apolinaire de Laodicée: Étude littéraire et doctrinale de l'Antirrheticus adversus Apolinarium et de l'Ad Theophilum adversus apolinaristas, Lyon 2008, 82-85 [thèse en langues, histoire et civilisations des mondes anciens, sous la direction de Olivier Munnich, présentée et soutenue publiquement le 19 novembre 2008, Lyon: Université Lumière, Institut Fernand Courby et Institut des sources chrétiennes]. I consulted this invaluable monograph at http://theses.univ-lyon2.fr/documents/getpart.php?id=1183\&action=pdf [22.10.2016]).

${ }^{28}$ Irenaeus Lugdunensis, Adversus haereses V, preface, PG7, 1120B: "qui propter immensam suam dilectionem factus est quod sumus nos, uti nos perficeret esse quod est ipse".
} 


\section{(Summary)}

The argument in the 380s between Gregory and Apolinarius, as set out Gregory's Antirrheticus adversus Apolinarium, can be seen as a significant step in the development of the Church's Christological teaching. Apolinarius's notion that the eternal Logos took the place of Jesus Christ's human mind is designed to establish the unity of his person, by providing a basis for the ontic continuity between the Second Person of the Trinity and Christ in his two natures. Commendably, he wants to counter any suggestion of separation between the human and divine natures ("two Christs"), which he sees as inevitably leading to an "adoptionist" view of Christ as a "God-filled man"; that would put Christ on the same level as the Old Testament prophets and could not form the basis of an adequate soteriology. Gregory argues convincingly however that Apolinarius's "enfleshed mind" Christology would mean that Jesus Christ was not fully human and could not therefore save humankind. But in the face of Apolinarius's challenge he cannot give an adequate account of Christ's unity during his earthly career. He remains open to Apolinarius's charge of a "divisive" Christology by in effect postponing the complete unity until after Christ's glorification, when his divinity overwhelmed his humanity and removed all his human characteristics, in the same way as the water of the sea overwhelms a drop of vinegar dropped into it. On this basis he has, anachronistically but not unreasonably, been accused of taking a Nestorian view of Christ before his glorification and a monophysite one after it. Both Apolinarius's stress on the unity of Christ and Gregory's on the notion that 'what is not assumed is not healed' (Nazianzen's phrase) were essential elements in what emerged seventy years later in the Chalcedonian definition.

\section{SPORY CHRYSTOLOGICZNE: APOLINARY Z LAODYCEI I ŚW. GRZEGORZ Z NYSSY}

\section{(Streszczenie)}

Spór między Apolinarym z Laodycei i Grzegorzem z Nyssy, mający miejsce w 380 r. i dotyczący dzieła tego ostatniego: Antirrheticus adversus Apollinarium, może być postrzegany jako istotny krok w rozwoju chrystologicznego nauczania Kościoła.

Pogląd Apolinarego, że odwieczny Logos zajął miejsce ludzkiego umysłu Jezusa Chrystusa, miał na celu ustanowienie jedności Jego osoby, zapewniając podstawę bytowej ciągłości między drugą Osobą Trójcy Świętej i Chrystusem w jego dwóch naturach. Słusznie chciał on przeciwdziałać wszelkiej sugestii rozdziału między ludzką i boską naturą („dwoma Chrystusami”), którą postrzega, jako nieuchronnie prowadzącą do „adopcyjnego” ujęcia Chrystusa jako człowieka „wypełnionego Bogiem” - stawiałaby ona tym samym Chrystusa na tym samym poziomie co proroków Starego Testamentu i jako taka nie mogłaby stanowić podstawy odpowiedniej soteriologii. 
Grzegorz z kolei przekonująco dowodzi, że chrystologia „wcielonego umysłu” Apolinarego oznaczałaby, że Jezus Chrystus nie był w pełni człowiekiem, a zatem nie może zbawić ludzkości. Jednak w obliczu zarzutów Apolinarego, nie może on dać odpowiedniego wyjaśnienia jedności Chrystusa w czasie Jego ziemskiego życia. Pozostawia bez odpowiedzi zarzuty Apolinarego odnośnie do „rozdzielającej” chrystologii, przez to, że w rezultacie przesuwa pełną jedność Chrystusa, aż do czasu po Jego uwielbieniu, kiedy to Jego boskość ogarnęła człowieczeństwo i usunęła wszystkie Jego ludzkie cechy w taki sam sposób, jak wody morza wchłaniają ocet wlany do niego. Na tej podstawie był potem oskarżany, anachronicznie, ale nie w sposób nieuzasadniony, o przyjmowanie nestoriańskiej (sformułowanej później przez Nestoriusza) wizji Chrystusa przed jego uwielbieniem i o pogląd monofizytyzmu po nim.

Zarówno, troska Apolinarego o jedność Chrystusa, jak i Grzegorza z Nyssy o sformułowanie: ,to, co nie zostało przyjęte, nie zostało zbawione” (wyrażenie Grzegorza z Nazjanzu), stały się istotnymi elementami, w oparciu o które siedemdziesiąt lat później powstała definicja chalcedońska.

Key words: Christology, Gregory of Nyssa, Apolinarius of Laodicea.

Słowa kluczowe: chrystologia, Grzegorz z Nyssy, Apolinary z Laodycei.

\section{BIBLIOGRAPHY}

\section{Sources}

Gregorius NaZianzenus, Epistulae, PG 37, 21-388.

Gregorius Nyssenus, Antirrheticus adversus Apollinarium, ed. F. Müller, GNO 3/1, Leiden 1958, 131-233.

Gregorius Nyssenus, De oratione dominica, ed. J. Callahan, GNO VII/2, Leiden 1992, 5-74.

Gregorius Nyssenus, Dialogus de anima et resurrectione, PG 46, 11-160.

Gregory of Nyssa, Anti-Apollinarian Writings, translated with an introduction, commentary and notes by R. Orton, The Fathers of the Church 131, Washington DC 2015.

Irenaeus LugdunEnsis, Adversus haereses, PG 7, 437-1224.

\section{Literature}

Alexopoulos T., Die Christologie Gregors von Nyssa in Contra Eunomium III 3-4: Die Beweisführung Gregors zur Einheit der Person Christi und das Problem des Verhältnisses der zwei Naturen zueinander in Ihm. Ist der Verdacht des Monophysitismus bei Gregor berechtigt?, in: Gregory of Nyssa Contra Eunomium III, An English Translation with Commentary and Supporting Studies, Proceedings of the 12th International Colloquium on Gregory of Nyssa (Leuven, 14-17 September 2010), ed. J. Leemans - M. Cassin, Supplements to Vigiliae Christianae 124, Leiden 2014, 477-488.

Grelier H., L'argumentation de Grégoire de Nysse contre Apolinaire de Laodicée: Étude littéraire et doctrinale de l'Antirrheticus adversus Apolinarium et de l'Ad Theophilum adversus apolinaristas, Lyon 2008; thèse en langues, histoire et civilisations des mondes anciens, sous la direction de Olivier Munnich, présentée et soutenue publiquement le 19 novembre 2008, Lyon: Université Lumière, Institut Fernand Courby 
et Institut des sources chrétiennes (http://theses.univ-lyon2.fr/documents/getpart. php?id=1183\&action=pdf [22.10.2016]).

Gunton C., The Barth Lectures, ed. P.H. Brazier, Edinburgh 2007.

Kelly J.N.D., Early Christian Doctrines, London $1993^{5}$.

Raven Ch.E., Apollinarianism: An Essay on the Christology of the Early Church, Cambridge 1923.

Young F.M. - Teal A., From Nicaea to Chalcedon: A Guide to the Literature and Its Background, London $2010^{2}$. 
